\title{
A Study of Several Financial Literacy Teaching Methods for Children
}

\author{
Jumadil Saputra ${ }^{1}$, Dwi Susanti ${ }^{2 *}$ \\ ${ }^{1}$ Faculty of Business, Economics, and Social Development, Universiti Malaysia Terengganu, 21030 Kuala Nerus, \\ Kuala Terengganu, Malaysia \\ ${ }^{2}$ Department of Mathematics, Faculty of Mathematics and Natural Sciences, Universitas Padjadjaran, Bandung, \\ Indonesia
}

*Corresponding author email: jumadil.saputra@umt.edu.my; dwi.susanti@unpad.ac.id

\begin{abstract}
Financial literation is very important to be applied to the child as early as possible. Financial literation will be very influential to the understanding and knowledge about finance and also the level of prosperity in the future. This paper aims to discuss several ways to teach children the functions and uses of money, and how to manage finance. The methods examined include: giving allowance to children, teach children to have savings, bring children do shopping, teach children to share, teach children that it takes effort to earn money and teach finance with a simple understanding. The results showed that the introduction of the knowledge of financial literacy in early age make children accustomed to manage their financial in the future. Therefore, parents must be able to effectively carry out financial literacy to children from an early age.
\end{abstract}

Keywords: Early childhood, financial literacy, teaching effectively, managing finances, welfare

\section{Introduction}

Introduce about the function and value of money to the children in early age is very important so the children can understand how to use the money. With simple things parents can teach how to manage finance with a way to save and sort out the use of money (Lusardi \& Mitchell, 2014). Children's is at the age that they are growing and developing, especially when children enter kindergarten school. At that age, a child usually has a high sense of curiosity and they also quickly absorb knowledge about new things. At that time parent can begin to introduce about financial to the children (Agrawal and Mazumder, 2013).

The way to introduce financial problems to children is not by directly introducing them to financial products but more fundamentally by explaining what money is. After they understand the function of money, parents can teach them how to manage finance. The simplest thing parents can do is provide an introduction to the concept of money to children. (Novieningtyas, 2018) explain what the function of money is so they understand how to use the money. Also introduce them to money based on the nominal value from the smallest fraction to the largest fraction. Therefore, children recognize the value of money and do not think all money is the same. Parents can start the practice by giving various kinds of real money in the form of banknotes and coins to the child and give a simple explanation of the differences between the two types of money, such as banknotes for large denominations and coins for small denominations (Saul, 1997; Sina, 2014). Children will certainly be interested in learning about this, especially the latest colorful Rupiah banknotes add to the child's appeal. However, it is necessary to remember to tell children that money is not for toys because money has a certain value, so it should not be lost (Sayinzoga et al., 2016; Behrman et al., 2012).

Several studies on financial literacy, are Rapih (2016), discussing why and how financial literacy education is very important to be applied to children as early as possible. The inculcation of financial literacy values as early as possible in children will greatly affect the understanding and knowledge of financial literacy and also the level of welfare in the future. The cognitive characteristics of children who are still concrete and still in the development stage are very effective in instilling financial literacy values. The family, which is the first community, is very effective as a place to instill the values of financial. The role of schools is also very important in providing knowledge about financial 
literacy education to children. Joint commitment and synergy of all parties is needed for the success of instilling financial literacy values through family or school.

Ariyani (2018), in a study saying that financial literacy is one of the basic literacies of the 21st century. Financial understanding is necessary to educate people to be aware and understand about how to manage finances wisely and according to need. Financial literacy education should be given as early as possible, namely pre-school children or early childhood. The introduction of financial literacy knowledge from an early age will make children accustomed to managing finances properly and correctly in the future. Kindergarten school teachers need to make efforts to make their students aspire to be entrepreneurs based on monotheism. The implementation of financial literacy education in kindergarten schools includes several scopes, namely the introduction of transactions, economic resources, the concept of spending, the concept of saving, the concept of sharing and the concept of financial bad practice. The distinctive character of the implementation of literacy education in kindergarten schools is to integrate it with monotheism.

Referring to the description above, this paper intends to study several financial literacy methods for children. The aim is to find out some methods to teach children the functions and uses of money, as well as how to manage finances for children. Thus, parents can carry out financial literacy to children effectively.

\section{Material and Methods}

The material used in this study is a number of articles sourced from several scientific works published in scientific journals, books, and articles published in electronic media through the website.

The method of study on how to teach financial literacy to children at early ages are include (https://www.cermati.com):

a) Giving allowance to the children; when children go to school, try to provide them with enough pocket money. Tell the children to use the money according to their needs, such as buying food or snacks during recess.

b) Teach children to saving; teach the children to save the surplus of their pocket money every day. If needs be, buy a piggy bank shaped of their favorite animals to add the motivation of children to save money.

c) Take children shopping; start to take your child to the market or the supermarket when shopping in order to introduce the practice of buying and selling directly. Let the children see how their parents' shop.

d) Teach children to share; the way to teach children to share can be by teaching them to give alms at worship places or give money to panhandlers.

e) Teach children that earning money takes effort; ingrain to children from the early age that the money is not solely given for free; rather, it takes effort, hard work and intelligence to get it.

f) Teach Financial Subjects with Simple Understanding; it should begin when the children enter school age. Teaching children to understand how to manage finances from an early age.

\section{Results and Discussion}

Giving Allowance to Children. Pocket money is one method that can be applied by parents to teach children the responsibility of managing his own money. Giving pocket money to children, starting at school age, helps them learn about the value of money. When children get pocket money, they have to make choices about what items to buy with the amount of money given, or how much money to save for savings. If they have to save part of their allowance, they will learn about waiting to get what they want. Allowance also helps children learn about the consequences of spending money. Allowing children to make mistakes, such as spending all the money on ice cream instead of waterproof sand sets is part of the learning process. To determine how much allowance parents give to their children, consider the family's financial resources, daily living expenses in the family area and a comfortable level for the parents. It all depends on the parents to decide the best amount. Do not give excessive money to children, so the things that are expected will be useless because the child will not learn to manage finances (https://www.popmama.com).

Teaching Children to Saving. Saving is a positive, profitable activity that can be taught to children. Teach children to save the excess of their pocket money every day. If necessary, buy a piggy bank in the shape of their favorite animal to motivate children to save. Also instill the proverb of saving is the root of wealth, while being extravagant is the root of poverty. In addition, tell children the benefits of saving, such as the results of the money saved will be collected a lot and can be used to buy the things they want. Teach children to put aside some money for savings is also believed to shape the behavior of saving in the child. For application, parents can do simple practices when children ask to buy a toy. Teach them to save to buy these toys. Ask the child how much money he can 
save per day from the remaining allowance, also find out how much the toy costs. Then help the child to calculate when the money will be sufficient to buy it (https://www.popmama.com).

Bring Children do Shopping. There are many lessons regarding finance that will be obtained by taking children to do shopping. Start taking children to the market or supermarket when shopping to introduce the practice of buying and selling directly. Let the children see how their parents shop. The child will of course know how to transact by paying a certain amount of money to get the purchasing items. There will be an additional lesson for children who are brought shopping to the market, namely that children will be familiar with the bargaining system in transactions. In addition, children will also record what they need to buy for their daily needs. This way, the child will know what are needed at home. It will also teach them how to choose what to buy; for example, choosing fresh fruit or vegetables so that they understand and can feel how to act as consumers. One of the most powerful methods for teaching children is learning while playing. Try to introduce finances to children through games such as through the game of monopoly. In a monopoly, children can learn the system sale and purchase while playing with a variety of nominal money (https://www.cermati.com).

Teaching Children to Share. In addition to teaching children to use money for commercial purposes, also teach children to share with others. Explain to children not to be wasteful in using money because not everyone has it. How to teach children to share can be by teaching them to do alms at places of worship or giving money to beggars. The old man must have been understood very well that charity was important for the development of the spirit and faith of a person. In addition, giving alms is a form of empathy and concrete actions to help others who are less fortunate. However, children are not going to be aware of this thing automatically. Parent's duty to instill these values to the children. The habit of charity should be taught as early as possible because it will train the child to be genuine and sincere when doing it. Thus, the charity not only be an obligation, but also the will of the children. That way the children sympathy for others will start to grow (https://www.cermati.com; https://www.orami.co.id).

Teach Children that Getting Money Requires Effort. Instill in children from an early age that money is not come casually, rather, it takes hard and smart effort and work to get it. The more a person works hard and smart, the more money will that person earn. After learning to know the money at the age of preschool and practice saving money and spend it correctly at preschool ages through early elementary school, parents can teach children how to generate money. From this, children will know and experience for themselves that making money is not an easy matter. However, the parents certainly do not mean to scare them to do this. This is useful for teaching children not to waste money. Indirectly, this method also teaches children to be diligent because there is an idea for them if it wants to get the more money, it is necessary to work that much as well (https://www.cermati.com).

Teach Financial Subjects with Simple Understanding. For those who have become parents, they should begin teaching financial matters to children as they enter school age. Of course, teaching about finance is not an easy matter. It needs the simplest possible explanation so that children can easily understand it. The mindset of children about how to get money is still very simple. Many children think that money can be given for free. Children's knowledge of money is still very limited and that is where the role of parents is to inform and provide a clear understanding of finances, from where money comes from to how it is managed. To introduce the financial system and how to manage finances for children, you don't need to be grandiose. Teaching children about finances can be through real-life examples around us. Like the previous examples of how to teach children about finance. There are many positive impacts that can be obtained by teaching this to children, one of which is that children understand how to manage finances from an early age. In addition, the introduction of financial matters is also expected to instill thriftiness in children (https://www.cermati.com; https://www.orami.co.id).

\section{Conclussion}

In this paper, a study of several methods of financial literacy in children has been conducted. Based on the results of the study, it can be concluded that there are several methods to teach children the functions and uses of money, as well as how to manage finances for children. From the results of this study, parents can understand how important it is to effectively teach financial literacy to children from an early age. Parents need to choose the right way to teach financial literacy to their children, wisely so that children can understand how money functions and uses and how to earn and manage money.

\section{References}

Agrawal, S., \& B. Mazumder. (2013). Cognitive Abilities and Household Financial Decision Making. American Economic Journal: Applied Economics, 5(1), 193-207.

Ariyani, D. (2018). Pendidikan Literasi Keuangan pada Anak Usia Dini di TK Khalifah Purwokerto. YIN YANG, 13(2), 175-190.

Behrman, J. R., Mitchell, O. S., Soo, C. K., \& Bravo, D. (2012). How Financial Literacy Affects Household Wealth Accumulation. American Economic Review: Papers and Proceedings, 102(3), 300-4. 
Lusardi, A., \& Mitchell, O. S. (2014). The Economic Importance of Financial Literacy: Theory and Evidence. Journal of Economic Literature, 52(1), 5-44.

Novieningtyas, A. (2018). Pentingnya Edukasi Literasi Keuangan Sejak Dini.

Rapih, S. (2016). Pendidikan Literasi Keuangan Pada Anak: Mengapa dan Bagaimana? Scholaria, 6(2), 14-28.

Saul, K. E. (1997). Money Matters: Exploring Money Concepts with Young Children. Dimensions of Early Childhood, 25(2), 1721.

Sayinzoga, A., Bulte, E. H., \& Lensink, R. (2016). Financial Literacy and Financial Behaviour: Experimental Evidence from Rural Rwanda. Economic Journal, 126(594), 1571-99.

Sina, P. G. (2014). Peran Orangtua Dalam Mendidik Keuangan Pada Anak (Kajian Pustaka). Ragam Jurnal Pengembangan Humaniora, 14(1), 74-86.

https://www.popmama.com/big-kid/6-9-years-old/winda-carmelita/mengajarkan-anak-mengelola-keuangan-dengan-metode-uangsaku/1

https://gln.kemdikbud.go.id/glnsite/pentingnya-pengenalan-literasi-keuangan-sejak-paud/

https://www.cermati.com/artikel/mengapa-mengenalkan-keuangan-bagi-anak-itu-penting-ini-alasannya.

https://www.orami.co.id/magazine/pentingnya-mengajarkan-anak-bersedekah-sejak-dini/

https://parenting.dream.co.id/ibu-dan-anak/5-contoh-cara-ajarkan-anak-tentang-keuangan--190727a.html. 